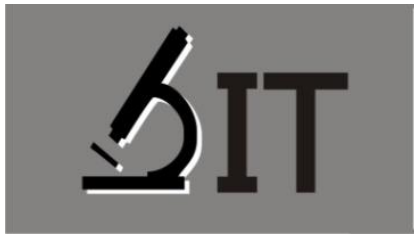

p-ISSN : 2597-8977

e-ISSN : 2597-8985

Sidiq Almien Syahwi*)

Prodi Pendidikan IPA FMIPA

Universitas Negeri Makassar

Nurhayani H. Muhiddin

Prodi Pendidikan IPA FMIPA

Universitas Negeri Makassar

Ramlawati

Prodi Pendidikan IPA FMIPA Universitas Negeri Makassar

*) Correspondence Author: sidiqalmiensyahwiigu@gmail.co $\mathrm{m}$
JIT 4 (1) (2020) 1-11

JURNAL IPA TERPADU

http://ojs.unm.ac.id/index.php/ipaterpadu

\section{PENGARUH MODEL PEMBELAJARAN KOOPERATIF TIPE THINK PAIR SHARE (TPS) TERINTEGRASI PRAKTIKUM TERHADAP HASIL BELAJAR IPA}

Abstrak: Penelitian ini bertujuan untuk mengetahui tingkat hasil belajar IPA peserta didik kelas VIII SMP Negeri 2 Balanipa yang dibelajarkan dengan model pembelajaran kooperatif tipe think pair share (TPS) dan konvensional pada materi pokok struktur dan fungsi tumbuhan dan ada tidaknya pengaruh model pembelajaran kooperatif tipe think pair share (TPS) terhadap hasil belajar IPA peserta didik kelas VIII SMP Negeri 2 Balanipa pada materi pokok struktur dan fungsi tumbuhan. Penelitian ini merupakan penelitian eksperimen semu (Quasi-Eksperiment) dengan desain penelitian Nonequivalent Control Group Design. Populasi penelitian ini adalah seluruh peserta didik kelas VIII SMP Negeri 2 Balanipa sekaligus sebagai sampel, yang terdiri dari 2 kelas. Instrument penelitian hasil belajar berupa tes hasil belajar berbentuk pilihan ganda yang berjumlah 25 item soal yang telah divalidasi ahli. Teknik pengumpulan data dalam penelitian ini adalah pemberian pretest dan posttest. Data dianalisis dengan statistik deskriptif. Hasil analisis deskriptif disimpulkan bahwa hasil belajar peserta didik kelas VIII SMP Negeri 2 Balanipa materi pokok struktur dan fungsi tumbuhan yang dibelajarkan dengan model pembelajaran Think Pair Share (TPS) pada berada pada kategori tinggi dengan rata-rata skor 17.58 dan yang dibelajarkan dengan model pembelajaran langsung berada pada kategori sedang dengan rata-rata skor 15.44 dan terdapat pengaruh model pembelajaran kooperatif tipe think pair share (TPS) terhadap hasil belajar IPA peserta didik kelas VIII SMP Negeri 2 Balanipa pada materi pokok struktur dan fungsi tumbuhan.

Kata kunci: Think Pair Share, hasil belajar, Praktikum

Abstract: This study aims to know the heigh level of learning outcomes of students of class VIII junior high school 2 Balanipa which is taught by using cooperative learning model type Think Pair Share and convensional on the subject matter of the struktur dan fungsi tumbuhan and the presence or absence of increase cooperative learning model type Think Pair Share of learning outcomes of students of class VIII junior high school 2 on the subject matter of the struktur dan fungsi tumbuhan. This research is a quasi-experimental research (Quasi-Experiment) with noquivalent control group design research design. The population of this research is all students of class VIII junior high school 2 Balanipa also as sample, which consist of 2 classes. The instruments used were learning outcomes 25 items of multiple choice had validated experts. Data collection technique were given pretest and posttest Data analysis was performed using descriptive analysis. The results of descriptive analysis, can be concluded that learning outcomes of students of class VIII junior high school 2 Balanipa on the subject matter of the struktur dan fungsi tumbuhan which is taught by using cooperative learning model type Think Pair Share 
is on high category with an average score 17.58 and which is taught by using direct learning is on medium category with an average score 15.44 and there was an increase cooperative learning model type Think Pair Share of learning outcomes of students of class VIII junior high school 2 on the subject matter of the struktur dan fungsi tumbuhan.

Keyword: think pair share, learning outcomes. practicum 


\section{PENDAHULUAN}

Pendidikan adalah proses interaksi guru dengan peserta didik yang bertujuan meningkatkan perkembangan mental yang mandiri dan utuh. Hal ini membuat peserta didik mempunyai peran sebagai pebelajar dan guru berperan sebagai fasilitator, motivator, dan evaluator dalam kegiatan belajar mengajar. Pemerintah telah melakukan berbagai upaya dalam rangka pencapaian tujuan pendidikan dengan melakukan pembaharuan pendidikan. Tercapainya tujuan tersebut berkaitan dengan proses pembelajaran yang berlangsung di sekolah dengan melibatkan pendidik dan peserta didik. IImu pengetahuan alam (IPA) berhubungan dengan cara mencari tahu tentang alam secara sistematis, sehingga IPA bukan hanya penguasaan kumpulan pengetahuan yang berupa fakta-fakta, konsep-konsep, atau prinsip-prinsip saja tetapi juga merupakan suatu proses penemuan.

Berdasarkan observasi yang telah dilakukan di SMP Negeri 2 Balanipa bahwa proses pembelajaran masih berpusat pada pendidik. Peserta didik hanya berpusat pada informasi yang diberikan serta menghafal materi yang didengar dan kurang memahami materi yang diajarkan sehingga keterlibatan peserta didik dalam proses pembalajaran masih kurang. Peserta didik cenderung menghafal daripada memahami materi yang diajarkan. Selain itu, proses belajar mengajar jarang melakukan praktikum.

Pencapaian hasil belajar IPA belum sesuai dengan yang diharapkan dan belum bisa mencapai kompetensi dasar sebelumnya, sehingga perlu diterapkannya model pembelajaran yang dapat meningkatkan jumlah peserta didik yang tuntas dalam pembelajaran struktur dan fungsi jaringan pada tumbuhan. Salah satu upaya menyikapi masalah tersebut, maka dibutuhkan model pembelajaran yang tepat untuk meningkatkan hasil belajar. Pembelajaran kooperatif (cooperative learning) merupakan bentuk pembelajaran dengan cara peserta didik belajar dan bekerja dalam kelompok-kelompok kecil secara kolaboratif yang bersifat heterogen (Rusman, 2016).

Kooperatif tipe Think Pair Share (TPS) merupakan model pembelajaran yang paling cocok digunakan. Think Pair Share (TPS) adalah pembelajaran yang dimulai dengan peserta didik memikirkan pertanyaan yang diajukan guru secara individual terlebih dahulu kemudian peserta didik bepasang-pasangan untuk berdiskusi, setelah itu tiap pasangan mempersentasikan hasil diskusinya. Dengan penggunaan model ini siswa tidak hanya aktif secara individual mereka, tetapi mereka akan aktif dalam kelompok. Sehingga sikap apatis terhadap teman tidak ada lagi.

Model pembelajaran kooperatif TPS adalah model pembelajaran yang efektif untuk meningkatkan aktivitas untuk lebih banyak waktu untuk mempelajari (Wardana, 2017). Pendekatan ini dikembangkan oleh Frank Lyman (1985), pendekatan ini memberikan kesempatan kepada peserta didik untuk bekerja sendiri serta bekerja sama dengan orang lain (Ratumanan, 2015). Kelebihan Model Kooperatif Tipe Think Pair Share, yaitu meningkatkan partisipasi, cocok untuk tugas sederhana, lebih banyak kesempatan untuk berkontribusi masing-masing anggota kelompok, interaksi lebih mudah, dan lebih mudah dan cepat membentuknya, dalam penerapannya hanya memerlukan satu pasang (dua siswa) dalam kelompoknya dan biasanya hanya dipasangkan dengan teman sebangkunya, kedekatan emosional antara teman sebangku lebih intern (mendalam) sehingga memudahkan dalam komunikasi, dan daya saing antar kelompok juga sangat terlihat.

Praktikum merupakan suatu metode pembelajaran dengan menggunakan metode ilmiah terhadap gejala-gejala sosial, psikis, maupun fisik yang dipelajari dan diteliti melalui percobaan atau penelitian di bawah kondisi praktikum (Windyariani, 2019). Kelebihan metode praktikum, yaitu peserta didik dapat mengalami sendiri suatu proses atau kejadian, peserta didik terhindar jauh dari verbalisme, memperkaya pengalaman dengan hal-hal yang bersifat objektif dan realistis, mengembangkan sikap berpikir ilmiah, hasil belajar akan terjadi dalam bentuk referensi dan internalisasi (Asmadi, 2008). 
Hasil belajar adalah perubahan perilaku mahasiswa akibat belajar. Perubahan perilaku disebabkan karena dia mencapai penguasaan atas sejumlah bahan yang diberikan dalam proses belajar mengajar. Pencapaian itu didasarkan atas tujuan pengajaran yang telah ditetapkan (Purwanto, 2016). Menurut Bloom (dalam Gunawan, 2012) menyatakan bahwa hasil belajar pada ranah kognitif, yaitu mengingat (Remember), memahami (Understand), menerapkan (Apply), menganalisis (Analyze), Mengevaluasi (Evaluate), menciptakan (Create).

Hasil penelitian yang telah dilakukan oleh Budiati (2018), bahwa pelaksanaan pembelajaran kooperatif tipe think pair share (TPS) pada pelajaran IPA materi bahan kimia dalam kehidupan membawa perubahan yang positif terhadap proses pembelajaran di kelas. Sebelum diadakannya perlakuan pembelajaran hanya terpusat pada guru sebagai pemberi informasi, dan setelah diterapkan pembelajaran kooperatif tipe TPS proses pembelajaran lebih berpusat pada peserta didik. Sejalan dengan penelitian yang dilakukan oleh Afoan, (2016) menyatakan bahwa model pembelajaran kooperatif tipe Think Pair Share (TPS) dapat meningkatkan hasi belajar kognitif peserta didik. Hal ini dilihat dari rata-rata pretestsebesar $34,06 \%$ mengalami peningkatan pada posttest sebesar $83,13 \%$ dengan peningkatan rata-rata pretest ke posttest sebesar $49,06 \%$, dan ketuntasan klasikal hasil belajar sebesar $87,50 \%$.

Berdasarkan latar belakang dan teori tersebut, maka tujuan penelitian ini sebagai berikut:

1. Untuk mengetahui tingkat hasil belajar IPA peserta didik kelas VIII SMP Negeri 2 Balanipa yang dibelajarkan dengan model pembelajaran kooperatif tipe think pair share (TPS) yang terintegrasi praktikum dan konvensional pada materi pokok struktur dan fungsi tumbuhan.

2. Untuk mengetahui pengaruh model pembelajaran kooperatif tipe think pair share (TPS) yang terintegrasi praktikum terhadap hasil belajar IPA peserta didik kelas VIII SMP Negeri 2 Balanipa pada materi pokok struktur dan fungsi tumbuhan.

\section{METODE}

Jenis penelitian yang digunakan adalah penelitian kuantitatif dengan metode penelitian eksperimen dan desain penelitian yang digunakan adalah Non Equivalent Control Group design. Penelitian dilaksanakan pada Semester Ganjil Tahun Pembelajaran 2019/2020. Penelitian dilaksanakan di SMP Negeri 2 Balanipa .

Pengambilan sampel pada penelitian ini dengan cara Non probability sampling, dengan teknik sampling jenuh yaitu teknik penentuan sampel bila semua anggota populasi digunakan sebagai sampel. Populasi dalam penelitian ini adalah seluruh peserta didik kelas VIII SMP Negeri 2 Balanipa. Adapun banyak sampel dalam penelitian ini adalah 28 peserta didik. Instrumen yang digunakan dalam penelitian ini yaitu tes hasil belajar IPA. Variabel yang diselidiki dalam penelitian ini yaitu Kooperatif Tipe TPS dengan hasil belajar IPA.

Data hasil belajar peserta didik diperoleh melalui pemberian tes hasil belajar kognitif yang dibuat dalam bentuk pilihan ganda sebanyak 25 butir soal. Bentuk soal dalam tes hasil belajar berada pada tingkatan $\mathrm{C}_{1}$ sampai $\mathrm{C}_{4}$ sesuai dengan ranah kognitif KD yang digunakan. 
Tabel 1. Kategori Skor Tes Hasil Belajar Peserta Didik

\begin{tabular}{cc}
\hline Interval Skor & Kategori \\
\hline $21-25$ & Sangat tinggi \\
$16-20$ & Tinggi \\
$10-15$ & Sedang \\
$5-9$ & Rendah \\
$0-4$ & Sangat rendah \\
\hline & (Sumber: Dimodifikasi dari Supardi (2015))
\end{tabular}

Tabel 2. Kriteria Tingkat N-Gain

\begin{tabular}{cc}
\hline Batasan & Kategori \\
\hline $0,7 \leq \mathrm{g} \leq 1,0$ & Tinggi \\
$0,3 \leq \mathrm{g}<0,7$ & Sedang \\
$0 \leq \mathrm{g}<0,3$ & Rendah \\
\hline
\end{tabular}

Data yang diperoleh dari sampel penelitian ini berupa data kuantitatif. Hasil penelitian meliputi tes hasil belajar peserta didik yang diolah menggunakan teknik statistik deskriptif. Statistik deskriptif berfungsi untuk mendeskripsikan objek yang diteliti melalui data sampel.

\section{HASIL DAN PEMBAHASAN}

\section{Hasil Penelitian}

Hasil analisis deskriptif menunjukkan deskripsi skor hasil belajar peserta didik yang diajar dengan menggunakan model pembelajaran think pair share (TPS) dan model pembelajaran langsung pada materi pokok struktur dan fungsi tumbuhan.

Tabel 3. Deskripsi Hasil Belajar Peserta Didik Pretest dan Posttest pada Kelas Eksperimen dan Kelas Kontrol

\begin{tabular}{|c|c|c|c|c|c|}
\hline \multirow{2}{*}{ No. } & \multirow{2}{*}{ Statistik } & \multicolumn{2}{|c|}{ Kelas Eksperimen } & \multicolumn{2}{|c|}{ Kelas Kontrol } \\
\hline & & Pretest & Posttest & Pretest & Posttest \\
\hline 1. & Jumlah sampel & 24 & 24 & 18 & 18 \\
\hline 2. & Skor tertinggi & 12 & 24 & 13 & 22 \\
\hline 3. & Skor terendah & 4 & 6 & 4 & 8 \\
\hline 4. & Skor rata-rata & 7.78 & 17.58 & 7.88 & 15.44 \\
\hline 5. & Standar deviasi & 2.27 & 4.99 & 2.26 & 3.84 \\
\hline 6. & Varians & 5.15 & 24.90 & 5.11 & $14 \cdot 75$ \\
\hline
\end{tabular}

Berdasarkan data Tabel 3 pretest hasil belajar peserta didik pada kelas kontrol memperoleh skor tertinggi 13 dan skor terendah 4, skor rata-ratanya 7.78 dengan standar deviasi adalah 2.26. Peserta didik pada kelas eksperimen memperoleh skor tertinggi 12 dan skor terendah 4, skor rata-ratanya 7.88 dan standar deviasi adalah 2.27. Sedangkan data posttest hasil belajar peserta didik pada kelas kontrol memperoleh skor tertinggi 22 dan skor terendah 8 , skor rataratanya 15.44 dengan standar deviasi adalah 3.84. Sedangkan, peserta didik pada kelas eksperimen memperoleh skor tertinggi 24 dan skor terendah 6, skor rata-ratanya 14.69 dan standar deviasi adalah 4.99 . 
Tabel 4. Kategori Tingkat Posttest Hasil Belajar Kelas Eksperimen dan Kelas Kontrol

\begin{tabular}{ccrrrr}
\hline \multirow{2}{*}{ Interval } & \multirow{2}{*}{ Kategori } & \multicolumn{2}{c}{ Kelas Eksperimen } & \multicolumn{2}{c}{ Kelas Kontrol } \\
\cline { 3 - 6 } & & Frekuensi & Persentase (\%) & Frekuensi & Persentase (\%) \\
\hline $21-25$ & Sangat tinggi & 7 & 29.17 & 1 & 5.56 \\
$16-20$ & Tinggi & 12 & 50.00 & 8 & 44.44 \\
$10-15$ & Sedang & 2 & 8.33 & 7 & 38.89 \\
$5-9$ & Rendah & 3 & 12.50 & 2 & 11.11 \\
$0-4$ & Sangat rendah & 0 & 0.00 & 0 & 0.00 \\
\hline & Jumlah & 24 & 100,00 & 18 & 100,00 \\
\hline
\end{tabular}

Tabel 4 menunjukkan bahwa frekuensi dan persentase hasil belajar kelas eksperimen dengan menggunakan model Think Pair Share (TPS), frekuensi posttest peserta didik kelas eksperimen pada kategori sangat tinggi dengan persentase $29.17 \%$, yang berada pada posisi kategori tinggi dengan persentase $50.00 \%$, kategori sedang dengan persentase $12.50 \%$, dan kategori rendah dengan presentase $12.50 \%$ dan sangat rendah $0.00 \%$. Jumlah peserta didik kelas eksperimen sebanyak 24 orang. Sedangkan pada kelaskontrol yang diajarkan dengan menggunakan model pembelajaran langsung pada kategori sangar tinggi dengan presentase $5.56 \%$, kategori tinggi dengan persentase $44.44 \%$, kategori sedang dengan persentase $38.89 \%$, kategori rendah dengan presentase $11.11 \%$, dan kategori sangat rendah $0.00 \%$. Jumlah keseluruhan peserta didik sebanyak 18 orang. Berdasarkan data tersebut dapat disimpulkan bahwa hasil belajar kelas eksperimen lebih tinggi dari hasil belajar kelas kontrol.

Tabel 5. Deskripsi Kategori N-gain Hasil Belajar Peserta Didik Kelas Eksperimen dan Kelas Kontrol

\begin{tabular}{llllll}
\hline \multirow{2}{*}{ Interval } & \multirow{2}{*}{ Kategori } & \multicolumn{2}{c}{ Kelas Eksperimen } & \multicolumn{2}{c}{ Kelas Kontrol } \\
\cline { 3 - 6 } & & Frekuensi & Persentase\% & Frekuensi & Persentase\% \\
\hline $0,70 \leq \mathrm{g} \leq 1,00$ & Tinggi & 8 & 33.33 & 2 & 11.11 \\
$0,30 \leq \mathrm{g}<0,70$ & Sedang & 12 & 50.00 & 10 & 55.56 \\
$0,00 \leq \mathrm{g}<0,30$ & Rendah & 4 & 16.67 & 6 & 33.33 \\
\hline Jumlah & & 24 & 100 & 18 & 100 \\
\hline
\end{tabular}

Tabel 5, deskripsi kategori N-gain hasil belajar peserta didik untuk kelas eksperimen pada kategori tinggi mendapatkan frrekuensi 8 peserta didik dengan persentase $33.33 \%$ sedangkan pada kelas kontrol mendapatkan frekuensi 12 peserta didik dengan persentase $50.00 \%$. Kategori sedang pada kelas eksperimen mendapatkan frekuensi 4 peserta didik dengan persentase $16.67 \%$, sedangkan pada kelas kontrol mendapatkan frekuensi 2 peserta didik dengan persentase $11.11 \%$. Kategori rendah pada kelas eksperimen mendapatkan frekuensi 10 peserta didik dengan persentase $55.56 \%$ sedangkan pada kelas kontrol mendapatkan frekuensi 6 peserta didik dengan persentase $33.33 \%$.

Tabel 6. Rata-rata Skor N-gain Hasil Belajar

\begin{tabular}{lcccc}
\hline Kelas & \multicolumn{2}{c}{ Skor } & \multirow{2}{*}{ Rata-rata Skor N-Gain Hasil Belajar } & Kategori \\
\cline { 2 - 3 } & Pre-Test & Post-Test & & \\
\cline { 1 - 3 } Eskperimen & 7.88 & 17.58 & & Sedang \\
Kontrol & 7.88 & 15.44 & 0,59 & Sedang \\
\hline
\end{tabular}


Tabel 6 diperoleh bahwa Skor rata-rata Pretest dan Posttest kelas eksperimen, yaitu 7.88 dan 17.58, sedangkan kelas kontrol, yaitu 7.88 dan 15.44. Rata-rata skor N-gain hasil belajar peserta didik untuk kelas eksperimen dan kelas kontrol berada pada kategori sedang, namun dengan skor yang berbeda, pada kelas eksperimen yaitu 0.59 , sedangkan pada kelas kontrol yaitu 0.45 .

Tabel 7. Persentase Pencapaian Indikator Posttest Hasil Belajar Peserta Didik

\begin{tabular}{cllcc}
\hline \multirow{2}{*}{ No } & \multicolumn{1}{c}{ Indikator } & \multirow{2}{*}{ No. soal } & \multicolumn{2}{c}{ Persentase pencapaian } \\
\cline { 3 - 5 } & & 2,6 & 62.50 & 63.89 \\
\hline 1 & Mendeskripsikan struktur dan fungsi akar & 2,6 & Kontrol\% \\
2 & $\begin{array}{l}\text { Membedakan struktur dan fungsi jaringan } \\
\text { akar }\end{array}$ & $3,9,10,11,12$ & 68.33 & 70.00 \\
& $\begin{array}{l}\text { Mendeskripsikan struktur dan fungsi batang } \\
3\end{array}$ & $5,14,15$ & 75.00 & 57.41 \\
& & & 65.28 & 53.70 \\
4 & Membedakan struktur dan fungsi batang & $8,16,18$ & 91.67 & 83.34 \\
5 & Mendeskripsikan struktur dan fungsi daun & 4,20 & 76.39 & 74.08 \\
6 & Membedakan struktur dan fungsi daun & $21,23,25$ & 54.17 & 35.18 \\
7 & Mendeskripsikan struktur dan fungsi bunga & $19,22,24$ & & 66.67 \\
8 & $\begin{array}{l}\text { Mendeskripsikan struktur dan fungsi buah } \\
\text { dan biji }\end{array}$ & 1,17 & 89.59 & 52.78 \\
9 & $\begin{array}{l}\text { Memberi contoh pemanfaatan teknologi } \\
\text { yang terilhami oleh struktur tumbuhan }\end{array}$ & 7,13 & 58.34 & 61.89 \\
\hline
\end{tabular}

Tabel 7 terlihat bahwa terdapat hasil persentase pencapaian indikator hasil belajar pada kelas eksperimen dan kelas kontrol. Pencapaian indikator yang paling tinggi pada kelas eksperimen dan kontrol adalah pada indikator 5. Mendeskripsikan struktur dan fungsi daun. Sedangkan pencapaian indikator yang paling rendah pada kelas eksperimen dan kontrol adalah pada indikator 7. Mendeskripsikan struktur dan fungsi bunga. Persentase rata-rata persentase pencapaian indikator hasil belajar peserta didik pada materi struktur dan fungsi tumbuhan pada kelas eksperimen adalah sebesar $70.92 \%$ dan kelas kontrol sebesar $61.89 \%$

\section{Pembahasan}

Hasil analisis statistik deskriptif Tabel 4.1 menunjukkan bahwa skor pretest, kelas eksperimen dan kelas kontrol tergolong rendah. Setelah diberi perlakuan dengan menggunakan model pembelajaran kooperatif tipe Think Pair Share (TPS) pada kelas eksperimen dan tanpa menggunakan model pembelajaran kooperatif tipe Think Pair Share (TPS) menunjukkan bahwa skor rata-rata posttest untuk kelas eksperimen lebih tinggi dibandingkan skor rata-rata posttest yang diperoleh kelas kontrol. Berdasarkan data tersebut diperoleh pada kelas eksperimen skor rata-ratanya 17.58 berada pada kategori tinggi sedangkan kelas kontrol skor rata-ratanya 15.44 berada pada kategori sedang. Hal ini membuktikan bahwa rata-rata hasil belajar yang diajarkan dengan menggunakan model pembelajaran kooperatif tipe Think Pair Share (TPS) lebih tinggi dari model pembelajaran langsung.

Faktor yang mempengaruhi hal tersebut karena pada kelas eksperimen menggunakan model pembelajaran kooperatif tipe Think Pair Share (TPS), dimana dalam pembelajaran dengan model kooperatif tipe Think Pair Share (TPS) peserta didik dituntut untuk memahami materi pelajaran dengan cara berpikir, berpasangan dan berbagi. Setiap peserta didik bertanggung jawab 
untuk memahami materi dengan cara berpikir sendiri terlebih dahulu, bertukar pikiran atau informasi dengan teman sekelompoknya. Sedangkan pada kelas kontrol yang menerapkan pembelajaran langsung, dimana pada saat proses pembelajaran peserta didik terlihat kurang aktif dalam menyimak dan banyak yang mengobrol dengan teman kelasnya, dan pada saat diskusi kelompok yang terdiri dari 5-6 orang membuat peserta didik yang lain hanya pasif dan yang lainnya bekerja sendiri mencari jawaban.

Penjelasan didukung oleh penelitian yang dilakukan oleh Asdar (2016) bahwa Model pembelajaran tipe Think Pair Share memberi kesempatan pada peserta didik untuk membangun pengetahuannya. Melalui tahap berpikir, peserta didik menggunakan pengetahuan awal yang mereka miliki dan mengembangkannya dengan membentuk pendapat sendiri. Pada tahap berpasangan, peserta didik belajar bekerjasama. Hal ini lebih memudahkan peserta didik karena mereka lebih leluasa dalam mengemukakan pendapat pada temannya sendiri sehingga mereka saling membelajarkan.

Rata-rata skor $\mathrm{N}$-gain hasil belajar peserta didik kelas eksperimen dan kelas kontrol berada pada kategori sedang namun dengan nilai $\mathrm{N}$-gain yang berbeda. Pada kelas eksperimen nilai $\mathrm{N}$ gain hasil belajar peserta didik yaitu 0,59, sedangkan pada kelas kontrol yaitu 0,45. Hal ini sesuai dengan penelitian Sugiharti (2018), bahwa model pembelajaran Think Pair Share (TPS) dapat dijadikan salah satu alternatif model pembelajaran di kelas untuk menciptakan pembelajaran yang efektif serta dapat meningkatkan hasil belajar matematika peserta didik. Selain itu ada keterkaitan yang positif antara hasil belajar dengan kemampuan awal peserta didik, dimana kemampuan awal peserta didik merupakan pondasi untuk menerima pengetahuan yang baru. Apabila peserta didik sudah memiliki kemampuan awal yang tinggi maka peserta didik tersebut dapat meraih hasil belajar yang maksimal.

Persentase pencapaian tiap indikator untuk kelas eksperimen lebih tinggi dibandingkan dengan kelas kontrol. Pencapaian indikator hasil belajar paling tinggi pada kelas eksperimen dan kontrol adalah pada indikator 5 mendeskripsikan struktur dan fungsi daun, yaitu pada kelas eksperimen terdapat $91.67 \%$ sedangkan pada kelas kontrol terdapat $83.34 \%$. Hal ini dikarenakan bentuk soal pada indikator tersebut hanya meminta peserta didik untuk mengingat dan memahami, dimana bentuk soal tersebut berada pada kategori mudah. Persentase pencapaian indikator hasil belajar paling rendah pada kelas eksperimen dan kontrol adalah indicator 7 mendeskripsikan struktur dan fungsi bunga, yaitu pada kelas eksperimen terdapat $54.17 \%$ sedangkan pada kelas kontrol terdapat 35.18\%. Pencapaian indikator terlihat sangat rendah disebabkan karena pada indikator ini peserta didik sulit mebedakan setiap bagian bunga. Peserta didik sulit membedakan antara putik dan benang sari, antara alat perkembangbiakan jantan dan betina.

Persentase pencapaian indikator berdasarkan yang paling besar selisihnya anatara kelas eksperimen dan kelas kontrol adalah indikator mendeskripsikan struktur dan fungsi buah dan biji. Hasil perhitungan persentase pencapaian indikator hasil belajar terdapat selisih $22.92 \%$. Pada kelas eksperimen peserta didiknya lebih memahami bentuk buah dilihat dari skor posttestnya lebih banyak menjawab benar. Sedangkan pada kelas kontrol peserta didik kurang memahami struktur dan fungsi buah dan biji hal ini dikarenakan proses pada perlakuan terhadap kelas kontrol dan kelas eksperimen berbeda, sehingga selisih antara kelas eksperimen dan kelas kontrol lebih besar.

Persentase pencapaian indikator 1 dan 2 pada kelas eksperimen lebih rendah dibandingkan dengan kelas kontrol. Hal ini dikarenakan pengaplikasian model di kelas eksperimen kurang membantu yang membuktikan bahwa kelas kontrol lebih tinggi dibandingkan kelas eksperimen. Selain itu, pemahaman mengenai materi akar merupakan paling mudah, sehingga kemungkinan untuk penguasaan materi bisa dipahami oleh kedua kelas. Dengan demikian metodenya perlu ditambahkan agar peserta didik dapat melakukan pengamatan di sekitar lingkungan sekolah, sehingga dapat mengenal objeknya secara langsung dan lebih mudah memahami struktur akar disertai dengan pejelasan fungsi akar. 
Meskipun demikian kelas eksperimen memperoleh persentase pencapaian yang lebih tinggi daripada kelas kontrol dilihat pada Tabel 4.3 rata-rata persentase pencapaian indikator hasil belajar kelas eksperimen yaitu $70.92 \%$ dan untuk kelas kontrol rata-rata presentase pencapaian indikator hasil belajar yang diperoleh yaitu $61.89 \%$. Hal ini berarti bahwa dalam pencapaian indikator hasil belajar kelas eksperimen yang diajar dengan menggunakan model pembelajaran kooperatif tipe Think Pair Share (TPS) lebih tinggi dibandingkan dengan menggunakan model pembelajaran langsung.

Penelitian yang dilakukan oleh Muslima (2015) bahwa persentase peserta didik di kelas eksperimen lebih tinggi dibandingkan kelas kontrol. Terdapat perbedaan hasil belajar antara siswa yang diajar menggunakan model pembelajaran kooperatif tipe think pair share (TPS) dengan peserta didik yang diajar menggunakan model pembelajaran langsung pada materi termokimia. Hasil perhitungan effect size terhadap hasil belajar sebesar $26,73 \%$ terhadap peningkatan hasil belajar.

Hal lain yang mendukung adanya pengaruh model pembelajaran kooperatif tipe Think Pair Share (TPS) terhadap hasil belajar peserta didik adalah dengan adanya lembar kerja peserta didik (LKPD) yang diberikan pada peserta didik. Pada kelas eksperimen peserta didik terlibat aktif dalam proses pembelajaran, terutama dalam mengerjakan LKPD peserta didik telihat tertarik mengerjakannya dengan berpasangan teman sebangkunya dalam setiap kelompok kemudian dipresentasikan di depan kelas. Hal ini dapat dilihat dari rata-rata salah satu aspek yang dinilai, yaitu pada tahap melengkapi tabel dan data pengamatan. Rata-rata pada kelas eksperimen lebih tinggi dibandingkan kelas kontrol.

Penelitian yang dilakukan oleh Muslima (2015) bahwa pemberian LKPD dapat memberikan kesempatan untuk menuangkan ide sendiri, memberikan gagasan dan berbagi dengan pasangannya dan kelompok lain. Sehingga berpengaruh terhadap hasil belajar karena dapat menguatkan penguasaan konsep melalui tahap-tahap dalam model pembelajaran kooperatif tipe think pair share (TPS). Pada tahap think, peserta didik dilatih agar dapat mengerjakan tugas secara mandiri. Sedangkan pada tahapan pair dan share peserta didik member kesempatan untuk berinteraksi dengan pasangan dan kelompok lain terhadap tugas yang diberikan.

Model pembeajaran kooperatif tipe think pair share (TPS) yang terintegrasi praktikum yaitu suatu model pembeajaran gabungan, dimana TPS yang hanya memiliki tiga tahapan didalam proses pembelajarannya ditambahkan satu proses praktikum. Proses praktikum itu sendiri diaksanakan diakhir proses pembeajaran. Penambahan praktikum ini untuk membantu peserta didik agar tidak hanya teori yang didapat, agar pesera didik tidak membayangkan teori yang ada. Ditambah tuntutan kurikulum yang mewajibkan agar peserta didik terampil sebagai penilaian keterampilan peserta didik.

\section{KESIMPULAN}

Berdasarkan hasil analisis data dan pembahasan maka dapat disimpulkan bahwa:

1. Hasil belajar peserta didik kelas VIII SMP Negeri 2 Balanipa materi pokok struktur dan fungsi tumbuhan yang dibelajarkan dengan model pembelajaran Think Pair Share (TPS) berada pada kategori tinggi dengan rata-rata skor 17.58 dan yang dibelajarkan dengan model pembelajaran langsung berada pada kategori sedang dengan rata-rata skor 15.44 .

2. Terdapat pengaruh model pembelajaran kooperatif tipe think pair share (TPS) terhadap hasil belajar IPA peserta didik kelas VIII SMP Negeri 2 Balanipa pada materi pokok struktur dan fungsi tumbuhan. 


\section{DAFTAR PUSTAKA}

Afoan, M. Y., Sepe, F., \& Djalo, A. (2016). Evektifitas Penerapan Model Pembelajaran Think Pair Share (TPS) Terhadap Hasil Belajar Dan Aktivitas Siswa Pada Materi Sistem Pernapasan Pada Manusia. Jurnal Pendidikan , Vol. 1, No. 10. 2054-2058.

Asdar, A. F. (2016). Pengaruh Pelaksanaan Model Pembelajaran Kooperatif Tipe Think Pair ShareTerhadap Hasil Belajar IPS Siswa. Journal Of EST, Volume 2, Nomor 2. 56-64.

Asmadi. (2008). Pendidikan \& Keperawatan. Jakarta: Katalog Dalam Terbitan (KDT).

Budiati, A. (2018). Efektivitas Pembelajaran Kooperatif Tipe Think Pair Share Untuk Meningkatkan Hasil Belajar IPA di MTs N Gondowulung. Jurnal Pendidikan Madrasah , Vol. 3, No. 1. 65-76.

Gunawan, I., \& Palupi, A. R. (2016). Taksonomi Bloom-Revisi Ranah Kognitif: Kerangka Landasan Untuk Pembelajaran, Pengajaran, dan Penilaian. Premiere Educandum Jurnal Pendidikan Dasar dan Pembelajaran , 98-117.

Hake, R. (1999). Analyzing Change Gain Score. America: American Education Research Methodology.

Handayani, R. D. (2017). Pengaruh Model Pembelajaran Kooperatif Tipe Think Pair Share Terhadap Hasil Belajar PKn Siswa di Kelas IV MI Terpadu Muhammadiyah Sukarame Bandar Lampung. Jurnal Pendidikan dan Pembelajaran Dasar , Vol. 4, No. 2. 107-123.

Purwanto. (2016). Evaluasi Hasil Belajar. Yogyakarta: Pustaka Belajar.

Ratumanan. (2015). Inovasi Pembelajaran Mengembangkan Kompetensi Peserta Didik Secara Optimal. Yogyakarta: Penerbit Ombak.

Sugiharti, E. H. (2018). Efektivitas Think Pair ShareTerhadap Hasil Belajar Matematika Ditinjau Dari Kemampuan Awal. Prosiding Seminar Nasional Etnomatnesia , 505-510.

Supardi. (2015). Penilaian Autentik Pembelajaran Afektif, Kognitif, dan Psikomotorik (Konsep dan Aplikasi). Jakarta: Raja Grafindo Persada.

Wardana, L. W. (2017). Implementation Of Collaborative Learning Model Thinking Pair Share (TPS) and Arias To Improve Student Learning Results In Entrepreneurship Subjects. International Journal Of Academic Research In Business and Social Sciences, Vol. 7, No. 7.435-444.

Windayariani, S. (2019). Pembelajaran Berbasis Konteks \& kreativitas. Yogyakarta: Grup Penerbit CV Budi Utama. 


\section{Sidiq Almien Syahwi}

Mahasiswa Program Studi Pendidikan IPA FMIPA UNM, aktif melakukan penelitian pada bidang Pendidikan IPA, dapat dihubungi melalui email: sidiqalmiensyahwiigu@gmail.com.

\section{Nurhayani H. Muhiddin}

Dosen Program Studi Pendidikan IPA FMIPA UNM, aktif melakukan penelitian pada bidang Pendidikan IPA, dapat dihubungi melalui email: nurhayanio8@gmail.com.

\section{Ramlawati}

Dosen Program Studi Pendidikan IPA FMIPA UNM, aktif melakukan penelitian pada bidang Pendidikan IPA, dapat dihubungi melalui email: ramlawati@unm.ac.id. 